\title{
Simulating the transport of broadcast coral larvae among the Southern Islands of Singapore
}

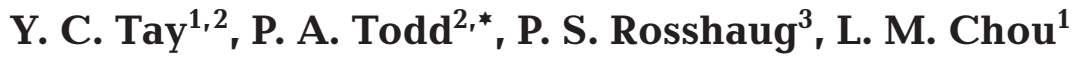 \\ ${ }^{1}$ Reef Ecology Laboratory, Department of Biological Sciences, National University of Singapore, 14 Science Drive 4, \\ 117557 Singapore \\ ${ }^{2}$ Experimental Marine Ecology Laboratory, Department of Biological Sciences, National University of Singapore, \\ 14 Science Drive 4, 117557 Singapore \\ ${ }^{3}$ DHI Water, Environment, Health, Agern Allé 5, 2970 Hørsholm, Denmark
}

\begin{abstract}
Singapore's coral reefs have experienced significant anthropogenic impacts for at least 4 decades. Ongoing reef restoration efforts, however, may not be sustainable if there is no natural coral recruitment. Knowledge of coral reef connectivity, which can be identified using hydrodynamic-advection and individual-based models, can help inform reef management decisions. Here, a 2-dimensional, hydrodynamic, flexible mesh model (MIKE 21 FM) coupled with a Lagrangian particle-tracking module was used to simulate larval transport among Singapore's Southern Islands. In each simulation, neutrally buoyant, passive particles representing coral planulae were released into the hydrodynamic conditions present during the coral multi-species synchronous spawning event of April 2007. When the number of larvae released was proportional to live coral cover (between 2400 and 46200 particles), 3 islands: Pulau Sudong, Pulau Pawai and Pulau Senang, which all lie within a military Live Firing Area, were identified as the most robust sources of larvae seeding the rest of the Southern Islands. However, when equal numbers of larvae (18 000 larvae per site) were released from all sites in an effort to identify nursery areas with the greatest potential to seed other reefs, 2 different and upstream islands, Sisters' Islands and Kusu Island, were found to be better sources of larvae. We suggest all 5 of these sites should be identified for conservation. Additional effort to enhance coral cover, and hence larval export, at Sisters' Islands and Kusu Island may help increase recruitment on downstream reefs.
\end{abstract}

KEY WORDS: Dispersal · Connectivity · Spawning $\cdot$ MIKE 21 FM $\cdot$ Conservation $\cdot$ Reef

\section{INTRODUCTION}

Coral reefs worldwide are being degraded by both human and natural disturbances (Hughes et al. 2003). The process of reef regeneration is slow, particularly in the face of frequent perturbations (Hughes et al. 1994, Sammarco 1996); hence, restoration approaches to enhance or encourage recovery are gaining considerable attention among reef managers. However, building coral nurseries or artificial reefs (Shafir et al. 2010) that are labour and costintensive may not be sustainable if there is no natural recruitment. The marine environment provides many opportunities for exchange of genetic material between conspecifics of different populations (Atchison et al. 2008), a key factor in natural, basal replenishment of reef stocks (Lipcius et al. 2008). This is especially true for broadcast spawners, including most scleractinian corals, which release gametes directly into the water column where fertilization occurs (Babcock \& Heyward 1986). Given their limited mobility (e.g. Szmant \& Meadows 2006, Gleason et al. 2009), the resultant larvae were thought to be almost entirely dependent upon water currents for dispersal and therefore also able to be distributed widely (e.g. Scheltema \& Williams 1983, Black 1993), leading to 
the paradigm that such marine populations are 'open'. Recent advances in population genetics and hydrodynamic-advection models, coupled with individual-based models, have increased the accuracy of larval dispersal predictions resulting in a conceptual shift to retention and 'closed' populations (Levin 2006, Atchison et al. 2008, Brazeau et al. 2011).

Population connectivity, of course, is not simply a matter of 'open' or 'closed' categories, but comes in a range between these 2 extremes (Cowen \& Sponaugle 2009). Connectivity should be defined according to the specific question at hand, which could have different temporal and spatial scale considerations (Oliver et al. 1992) or be viewed from very different perspectives. For example, fishery and coral reef managers are more likely to be interested in regular levels of larval transport among reefs that are responsible for ecological connectivity rather than sporadic events that might lead to historical or evolutionary connectivity. Many variables affect larval dispersal including regional geography, bathymetry and hydrodynamics (e.g. Sammarco et al. 1991, Black 1993), predator density (Fitzhardinge 1985) and various larval characteristics (as reviewed in Pineda et al. 2007, 2010), making it difficult to generalize connectivity patterns (Cowen \& Sponaugle 2009); hence, question- and site-specific studies need to be conducted at appropriate spatial scales and time frames if reliable predictions are to be made. In Singapore, we are interested in strategizing coastal resource management efforts to suit the needs of a country undergoing rapid economic development.

Since tracking the dispersal of tiny planktonic larvae in the ocean directly is almost impossible, many researchers have adopted indirect methods that include the use of genetic markers and numeric hydrodynamic models (e.g. Kool et al. 2011). The great majority of published work on planktonic larval dispersal using numerical models focuses on commercial fisheries (e.g. Pedersen et al. 2006, Savina et al. 2010) or pelagic larvae in general (e.g. Mitarai et al. 2008). It is evident even in recent publications that the major challenge faced by larval dispersal modellers across a wide range of taxa continues to be the paucity of knowledge of the biological properties of larvae that affects their dispersal (e.g. Savina et al. 2010, Tilburg et al. 2010). Broadcasting species of coral are well known for their multi-specific synchronous spawning events, and accurate data on times of gamete release have been incorporated into some model simulations (e.g. Lugo-Fernández et al. 2001, Baums et al. 2006). This information is vital as seasonal differences in the environmental conditions and hydrodynamic regimes can dramatically alter the dispersal patterns of gametes and larvae (Gilbert et al. 2010, Galindo et al. 2010, Roughan et al. 2011).

Singapore's coral reefs have experienced significant anthropogenic influence for at least 4 decades and are represented by the loss, degradation and modification of these important habitats (e.g. Sanderson 2001, Chou \& Tun 2005, Chou 2006). There is currently $<50 \mathrm{~km}^{2}$ of coral reef left, $\sim 40 \%$ of what existed 50 yr ago (Goh et al. 2007). The many stretches of straight edge along part of the southern coast of Singapore (see Fig. 2) are the result of extensive land reclamation activities. Nonetheless, the remaining reefs continue to support a diverse array of marine life (Chou \& Tun 2005, Huang et al. 2006a,b). Huang et al. (2009) recorded 255 species of scleractinian corals around the cluster of reefs south of mainland Singapore, the 'Southern Islands', a number comparable to other more extensive and less affected reefs in the region. Previously, little was done to conserve Singapore's remaining coastal ecosystems (Sanderson 2001); however, during the past $7 \mathrm{yr}$, the National Parks Board in Singapore has been coordinating efforts to build a science-based coastal management approach by providing strong support to various research projects that can help policy makers make targeted and better informed decisions (Goh 2009). Currently, only 2 nature reserves (i.e. protected by law) encompass marine systems: an area of mangrove on the north coast and a $300 \mathrm{~m}$ section of rocky shore and reef flat at Labrador beach-the only unmodified stretch of shoreline on the $>60 \mathrm{~km}$ south coast of mainland Singapore (Todd $\&$ Chou 2005). Some of the reefs, interestingly, are (indirectly) protected because they fall within or near areas that are important to Singapore's national interests, such as military live firing areas and a major offshore landfill (Chou \& Tun 2007).

To date, no studies have examined the source-sink dynamics of coral larval dispersal among the reefs of the Southern Islands of Singapore. Such information is important because reefs which are highly dependent upon external input have to be managed differently from those that self-recruit (Tuck \& Possingham 2000). Furthermore, a marine protected area network can only be effective when the reefs involved are within the dispersal ranges of coral larvae (Palumbi 2003). The complex hydrodynamics within the Singapore Strait (Chen et al. 2005) makes the Southern Islands an interesting archipelago to explore the effects of local hydrodynamics on planulae transport (and thus the potential for recruitment). The coral reefs are highly impacted, especially by sediment 


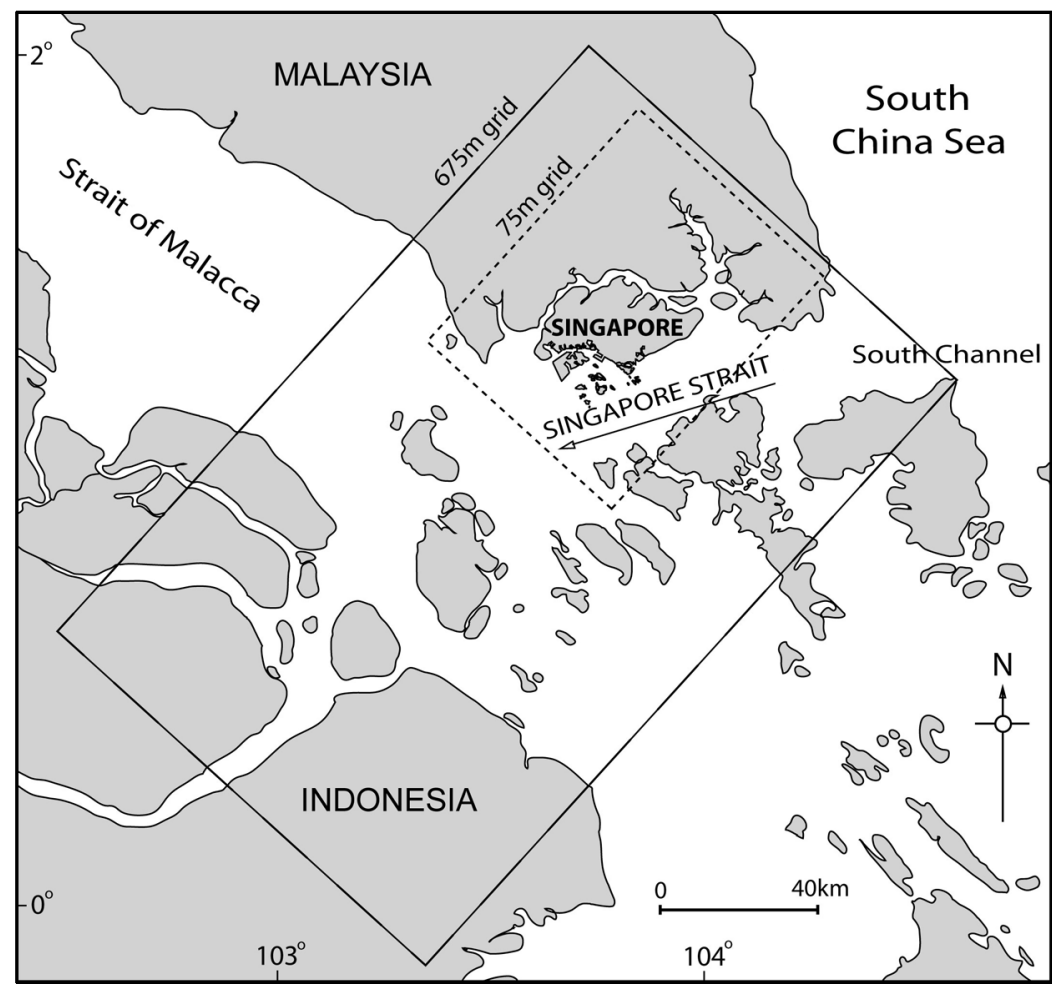

Fig. 1. Singapore showing the Southern Islands offshore and the Singapore Strait joining the South Channel and the Straits of Malacca. The 675/225/75 m MIKE21 nested grid model of the Singapore Strait is indicated: its overall regional $675 \mathrm{~m}$ grid model (large rectangle, solid lines) with doubly nested local $75 \mathrm{~m}$ grid (small rectangle, dashed lines) sub-domain model are shown (the $225 \mathrm{~m}$ grid is not shown). The arrow indicates the direction of the seasonal (net) westward current within the Singapore Strait during the coral spawning season

reefs and (3) determine source sites that could potentially be restored or enhanced as coral nursery grounds. These results will help define conservation strategies for Singapore's reefs as well as contribute to our understanding of local population dynamics.

\section{MATERIALS AND METHODS}

\section{Study area}

The area of interest spans approximately $110 \mathrm{~km}$ from the western end of the Singapore Strait $\left(1^{\circ} 6^{\prime} 0^{\prime \prime} \mathrm{N}\right.$, $\left.104^{\circ} 7^{\prime} 0^{\prime \prime} \mathrm{E}\right)$ to the South Channel $\left(1^{\circ} 16^{\prime} 0^{\prime \prime} \mathrm{N}, 104^{\circ} 25^{\prime} 0^{\prime \prime} \mathrm{E}\right)$ (Fig. 1). The study was performed for the coral reefs located south of the Singapore mainland, within the Singapore Strait. Local circulation patterns are directed mainly by trade winds, the Asian monsoons and tidal forcing (Chen et al. 2005). The Singapore Strait is narrow and tidal range differences between its 2 ends (which open into the South China Sea and northern Indian Ocean) can create a strong hydrodynamic pressure that drives water flow. During the 2 monsoon seasons, this pres-

resuspended by dredging of shipping lanes and land reclamation activities (Chou 1996) and, occasionally, entire reefs are reclaimed or merged. In natural resource-scarce nations such as Singapore, it is imperative to identify areas that are potentially important sources of larvae to prioritize conservation objectives and efforts.

Singapore's reefs extend from the southern coast of mainland Singapore to up to $13 \mathrm{~km}$ offshore to the south. As most islands are no farther than $4 \mathrm{~km}$ from the next reef (see Fig. 2) a high degree of connectivity may be expected. The present study uses a sophisticated flexible mesh hydrodynamic model coupled with a particle-tracking Lagrangian module to simulate larval transport at a local scale. The timing of particle release was based on coral multispecies synchronous spawning data collected during previous work (Guest et al. 2002, 2005). From these models, we aim to (1) predict the self-sustainability of the reef system in Singapore, (2) identify the strongest source and sink sites and predict the network of likely larval exchange among Singapore's sure gradient causes a net east to west flow from November to March, and a west to east flow from June to September (Tkalich et al. 2002, Chen et al. 2005). The simulated time period for this research, i.e. during the $12 \mathrm{~d}$ following the coral multi-species spawning in April 2007, was shortly after the main northeast monsoon season, when a seasonal net westward water movement (Pang \& Tkalich 2003) was still apparent.

\section{Hydrodynamic model}

A 2D flexible mesh model (MIKE 21 FM) was used to simulate the hydrodynamic flow in the Singapore Strait. This model has been used previously for other complex coastal regions (e.g. Jones et al. 2007, Lawrence et al. 2009, Sundelöf \& Jonsson 2012). In contrast to other published hydrodynamic models that typically use coarser (e.g. $800 \mathrm{~m}$ ) grid sizes owing to the larger geographical area covered (e.g. Fiechter et al. 2008, Ayata et al. 2009), we present 
one of the few small-scale studies to use a high resolution flexible mesh (down to $40 \mathrm{~m}$ ). The hydrodynamic model solved the $2 \mathrm{D}$ shallow water equations in a computational mesh in order to simulate the dynamic depth-integrated horizontal current field (DHI 2009). A detailed description of the model can be found in Babu et al. (2005). The overall structured regional hydrodynamic model grid employed is presented in Fig. 1. Output from this was used to extract the boundary data for the local unstructured hydrodynamic model. The boundaries were based on tidal constituents that also included typical seasonal wind variation. Bathymetric survey data were taken directly from digital navigation charts, supplemented by survey data where available. The model was rotated $40^{\circ}$ counter clockwise from North to improve boundary flow description. All water depths referred to Singapore Chart Datum, while the modelling and resultant presentations used the Singapore SVY21 co-ordinate system.

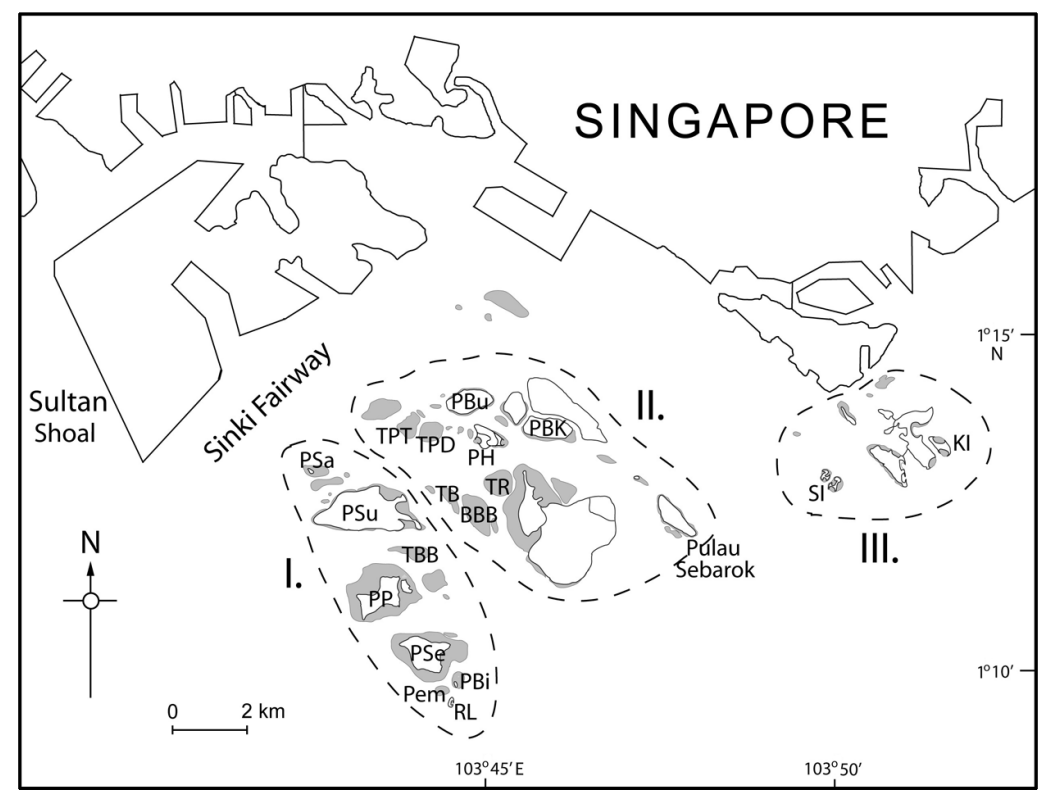

Fig. 2. The Southern Islands offshore from Singapore. Grey areas: coral reefs. Abbreviations of the 18 source reefs are as follows: RL: Raffles Lighthouse; SI: the Sisters' Islands; KI: Kusu Island; PH: Pulau Hantu; PBi: Pulau Biola; PBu: Pulau Busing; PBK: Pulau Bukom Kechil; Pp: Pulau Pawai; PSa: Pulau Salu; PSe: Pulau Senang; PSu: Pulau Sudong; BBB: Beting Bemban Besar; Pem: Pemalang; TBB: Terembu Berkas Besar; TB: Terembu Bemban; TPD: Terembu Pempang Darat; TPT: Terembu Pempang Tengah; TR: Terembu Raya. Dotted lines define the 3 zones of reefs, i.e. southwestern (I.), central (II.) and eastern (III.) clusters

\section{Model performance and validation}

The performance of the hydrodynamic model (developed and calibrated by DHI Water \& Environment, Singapore, since 2001) was adjusted for any changes in bathymetry owing to marine construction works (that may affect the hydrodynamics). The model was extensively calibrated and validated according to international specifications of the Foundation for Water Research (Doorn-Groen 2007), especially in terms of tidal dynamics. Real time daily current measurements at several sites in the Sinki Fairway (Fig. 2) were used to further test and calibrate the model. A demonstration of the model's performance as measured at 2 of the monitoring sites, Sultan Shoal and Pulau Sebarok (Fig. 2), is provided in Fig. 3.

\section{Particle tracking}

The Lagrangian add-on particle-tracking module was used to determine the faith of each particle in space. The particle tracking was a random walk model that used a Lagrangian discrete parcels method to simulate the distance increments of the particles as a result of drift and dispersion. The propagation step was solved using an explicit Euler method:

$$
\begin{gathered}
x_{n}=x_{n-1}+U\left(x_{n-1}, y_{n-1}, z_{n-1}, t_{n-1}\right) \Delta t+\sqrt{2 D_{h} \Delta t} \cdot r n d \\
y_{n}=y_{n-1}+V\left(x_{n-1}, y_{n-1}, z_{n-1}, t_{n-1}\right) \Delta t+\sqrt{2 D_{h} \Delta t} \cdot r n d \\
z_{n}=z_{n-1}
\end{gathered}
$$

where $x, y$ denote cartesian spatial coordinates, $z$ is the vertical coordinate, $n$ denotes the time step number, $t$ represents time, $\Delta t$ is the timestep, $U$ and $V$ denote horizontal velocity components in the $x$ and $y$ directions at the particle's spatial position, and $D$ is the horizontal dispersion coefficient. The horizontal velocity components are estimated during simulation from the depth-integrated hydrodynamic velocity fields and the particles' vertical position, assuming that the current profile is a bed shear profile (DHI 2011). The rnd term was a random number drawn from a normal distribution with mean 0 and variance 1 ; i.e. $N(\mu=0, \sigma=1)$. The horizontal dispersion coefficient $D_{h}$ was assumed to be equal to the horizontal turbulence simulated as the horizontal eddy viscosity in the hydrodynamic module using the Smagorinsky 

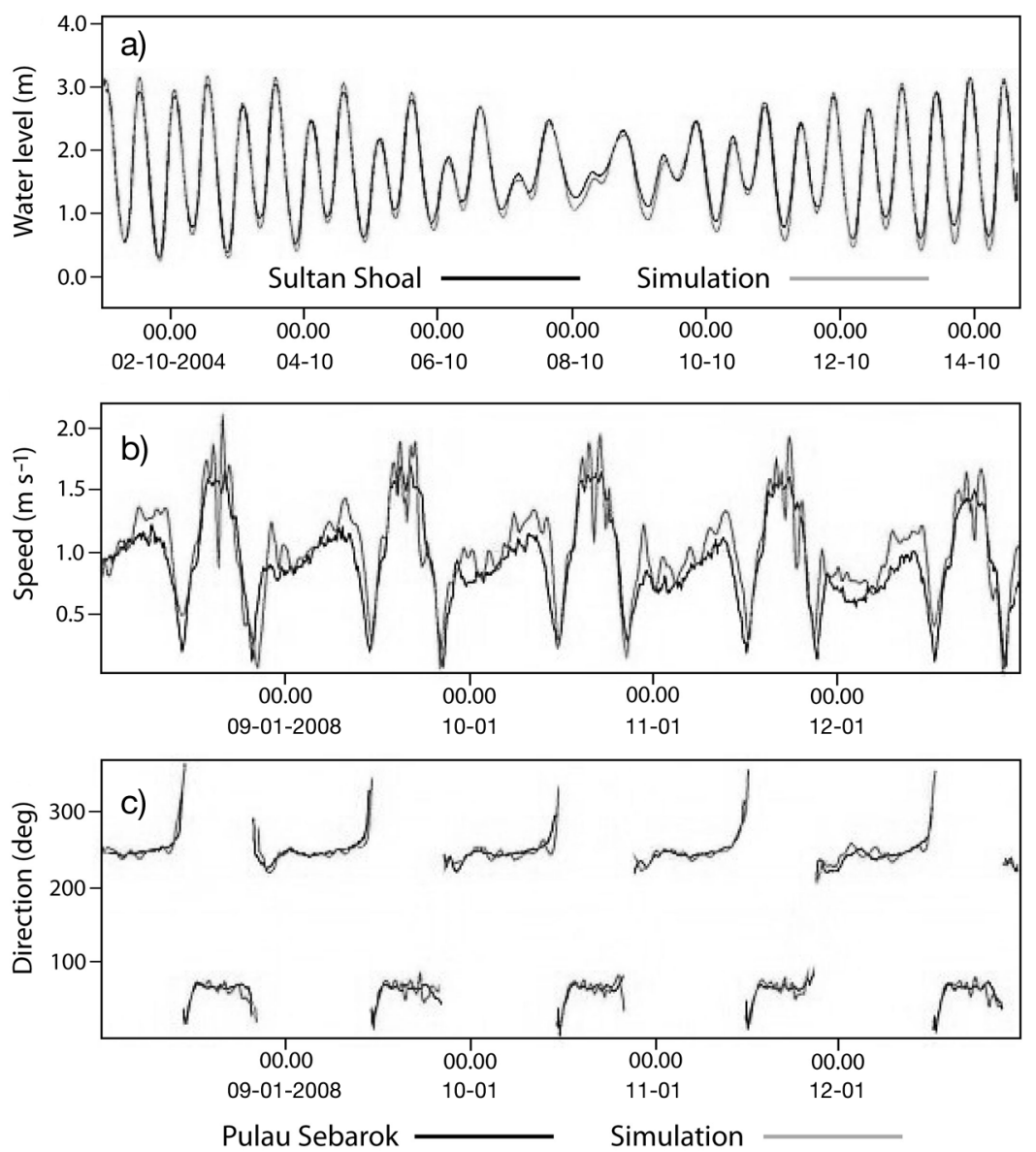

Fig. 3. Comparisons of actual field measurements and model predictions of the water level, current speed and direction at 2 of the monitoring sites, Sultan Shoal and Pulau Sebarok. All the root mean square (RMS) error values met the cut-off criteria. (a) Predicted and measured water levels at Sultan Shoal in 2004. RMS error was $0.12 \mathrm{~m}(<0.28 \mathrm{~m}$ criterion). Performance of the (b) speed and (c) direction as measured by the regional model complex against current measurements at Pulau Sebarok via a bottommounted acoustic Doppler current profiler in 2008. RMS errors for the speed and direction were $0.19 \mathrm{~m} \mathrm{~s}^{-1}$ and $18.4^{\circ}$, re-spectively $\left(<0.32 \mathrm{~m} \mathrm{~s}^{-1}\right.$ and $20^{\circ}$ criteria). Dates are dd-mm-yy and dd-mm

formulation. Details about the Smagorinsky formulation can be seen in DHI (2009). By applying a horizontal dispersion coefficient scaled to the horizontal eddy viscosity, the particles dispersed horizontally as a function of the simulated horizontal turbulence in the water. The scaling parameter was a calibration parameter, set to a value of 1 in this case.

Owing to the deficit of knowledge about the vertical position of coral larvae (Tay et al. 2011), the larvae particles were assumed to be neutrally buoyant and passive. The natural vertical dispersion of coral larvae was also unknown and therefore not included as a parameter. Erosion, decay and settling rates were also not included in these simulations. The drift profile of each particle was determined by data derived from the hydrodynamic model, with each time step set at $300 \mathrm{~s}$. A minimum particle mass of $1 \times 10^{-11} \mu \mathrm{g}$ was used to ensure the program did not record artefact particles with no mass, and a maximum particle age was set at $19 \mathrm{~d}$ to ensure all relevant particles were tracked until the end of the simulations.

\section{Model simulations}

Both brooded and broadcast-spawned coral planulae are simple, uniformly ciliated larvae that swim at speeds of $<0.4 \mathrm{~cm}$ $\mathrm{s}^{-1}$ (e.g. Szmant \& Meadows 2006, Gleason et al. 2009). Based on these studies, plus additional information on swimming of larvae for other marine invertebrates (Chia et al. 1984), 3 assumptions on the larvae from broadcast-spawning corals were made for the purpose of these model simulations: (1) swimming speed was not significant compared with the tidal currents (Sammarco 1994), (2) the direction of movement was random and (3) net distance moved by active larval swimming was therefore low. As we were looking into the largest possible range of larval transport from the reefs, the model was instructed to treat larvae as neutrally buoyant, fully planktonic (non-motile) particles that did not settle or die.

Coral spawning times for the simulations were based on data that were collected in 2007 surveys conducted by the Marine Biology Laboratory at the National University of Singapore (J. R. Guest \& K. P. P. Tun unpubl. data). Coral spawning was documented from 3 to $5 \mathrm{~d}$ after the full moon on 3 April, between 20:00 and 22:00 h. Similar spawning times were also documented in 2002 and 2003 (Guest et al. 2002, 2005). Particles representing coral larvae were therefore released at source reefs in the larval dispersal simulations on 7 April 2007 from 20:30 to 21:00 h, i.e. during the time when coral spawning in Singapore is generally most intensive. Even though the mass spawning data were collected mostly from the coral reefs off the western shore of Raffles Lighthouse $\left(1^{\circ} 9^{\prime} 35^{\prime \prime} \mathrm{N}\right.$, $103^{\circ} 44^{\prime} 26^{\prime \prime} \mathrm{E}$ ), such spawning 3 to $6 \mathrm{~d}$ after the full moon was also documented at another reef at Pulau Hantu in $2003\left(1^{\circ} 13^{\prime} 32^{\prime \prime} \mathrm{N}, 103^{\circ} 44^{\prime} 58^{\prime \prime} \mathrm{E}\right.$ ) (Guest et al. 2005), Kusu Island $\left(1^{\circ} 13^{\prime} 25^{\prime \prime} \mathrm{N}, 103^{\circ} 51^{\prime} 38^{\prime \prime} \mathrm{E}\right)$ in 

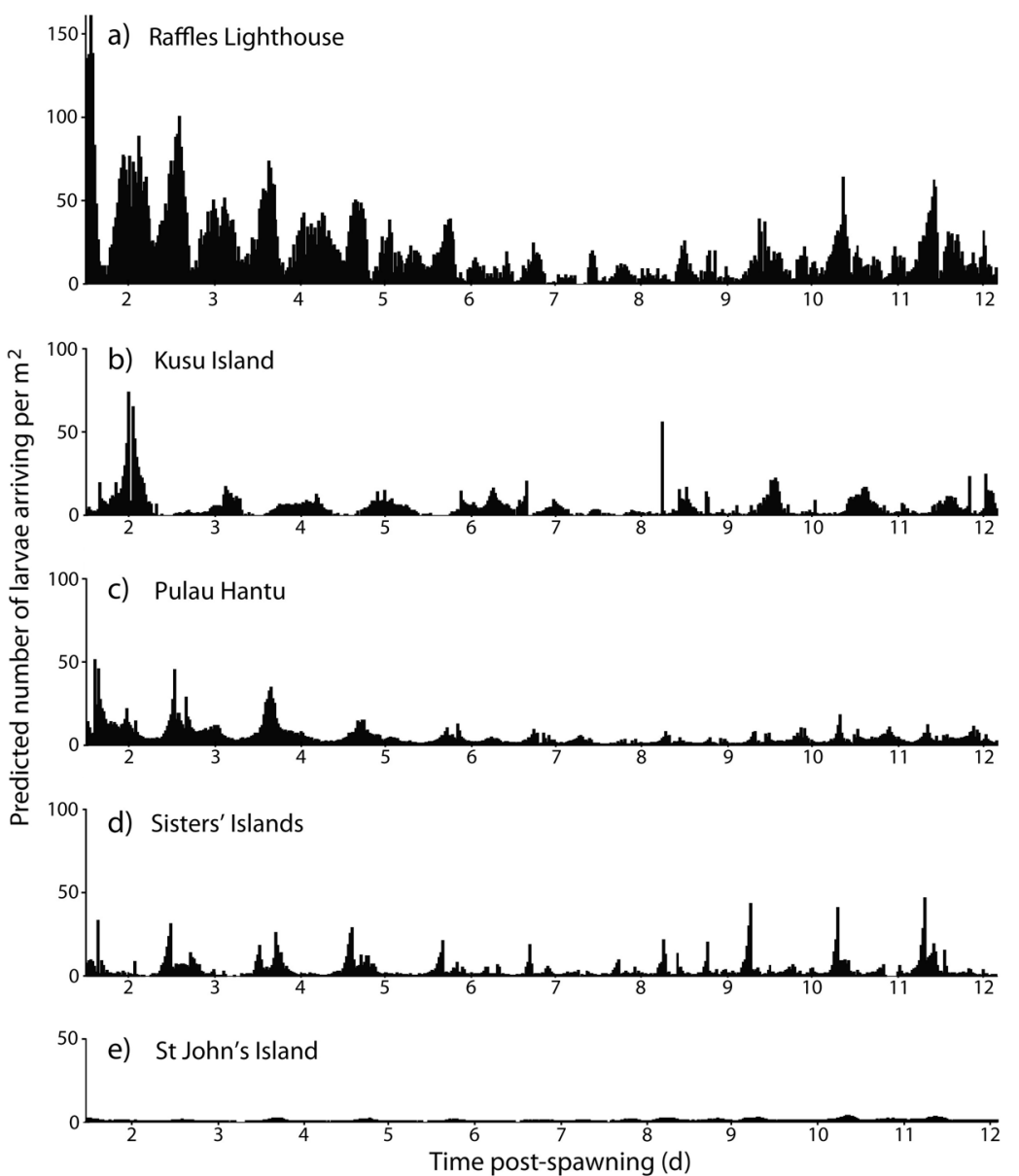

Fig. 4. The predicted number of coral larvae at each of the 5 sink sites: (a) Raffles Lighthouse, (b) Kusu Island, (c) Pulau Hantu, (d) the Sisters' Islands and (e) St John's Island, for the $12 \mathrm{~d}$ following the April 2007 multi-species spawning event. Data for the first $36 \mathrm{~h}$ are not presented as larvae would not be ready to settle during this period

2004 (unpubl. data) and Pulau Hantu and Pulau Se-

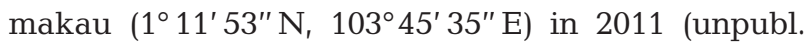
data) (Fig. 4). With the assumption that most of the reefs within the Southern Islands spawn synchronously during the same $2 \mathrm{~h}$ period, 18 potential source reefs were included in the model simulations.

\section{Set I simulations}

To provide an estimate of current connectivity patterns, including the larval exchanges between several reefs and, more specifically, to identify important sources and sinks, only coral reefs among the Southern Islands with $>25 \%$ live coral cover were considered in the model. From 2400 to 46200 particles (Table 1) were released between 20:30 and 21:00 h at each of the 18 source reefs (Fig. 2), the number of particles being proportionate to the live coral cover at each reef. The models were run from $2 \mathrm{~d}$ before to $12 \mathrm{~d}$ after the release of particles to cover the common peak larval settlement competency periods of coral larvae (e.g. Miller \& Mundy 2003, Tay et al. 2011). Data from the model simulations were saved every $30 \mathrm{~min}$. Larger numbers of particles, a longer simulation period or more frequent saving of data would have slowed computing time considerably.

\section{Set II simulations}

We also set out to distinguish between the influences of spawn release location and reproductive output on larval transport in order to identify sites that may be restored or enhanced as larval sources (nursery sites) for the seeding of other reefs. An equal number of particles were released from each site in this set of simulations. This set of model simulations was run with releases of 18000 particles from each source reef during the same time frame, with all other conditions remaining unchanged.

\section{Data extraction}

As most broadcasted larvae are not yet competent to settle within the first $36 \mathrm{~h}$ after spawning (e.g. Miller \& Mundy 2003, Tay et al. 2011) owing to required planktonic development time in the water column, data from this period were not used. Five existing reefs, where coral larval settlement and recruitment studies have been conducted previously (Loh et al. 2006, Tanzil et al. 2008), were selected as potential larval recruitment sites for the purpose of this study: Raffles Lighthouse, Kusu Island, Pulau Hantu, St John's Island $\left(1^{\circ} 13^{\prime} 09^{\prime \prime} \mathrm{N}, 103^{\circ} 50^{\prime} 56^{\prime \prime} \mathrm{E}\right)$ and the Sisters' Islands $\left(1^{\circ} 12^{\prime} 53^{\prime \prime} \mathrm{N}, 103^{\circ} 50^{\prime} 02^{\prime \prime} \mathrm{E}\right)$. Potential settlement sites were categorized into 3 zones - the southwestern (I.), central (II.) and eastern (III.) clusters (see Fig. 2) — for ease of analysis and discussion. Data for Set II simulations were extracted for only 3 of the sink sites: Raffles Lighthouse, Pulau Hantu and the Sisters' Islands, which represented the main zones of the southern islands (southwestern, central and eastern clusters, respectively). Particles per unit volume of water were 
Table 1. Details of the 29 sites (from 18 source reefs) in the Southern Islands, Singapore, from which particles were released

\begin{tabular}{|c|c|c|c|c|c|c|}
\hline Source reef name & Reef type & $\begin{array}{l}\text { No. sites } \\
\text { of release }\end{array}$ & $\begin{array}{l}\text { Release location } \\
\text { on reef }\end{array}$ & $\begin{array}{l}\text { Longitude } \\
\qquad\left({ }^{\circ} \mathrm{E}\right)\end{array}$ & $\begin{array}{l}\text { Latitude } \\
\left({ }^{\circ} \mathrm{N}\right)\end{array}$ & $\begin{array}{l}\text { No. particles } \\
\text { released per } 300 \mathrm{~s}\end{array}$ \\
\hline Beting Bemban Besar (BBB) & Patch & 1 & West & 103.74 & 1.21 & 500 \\
\hline Kusu Island (KI) & Fringing & 1 & East & 103.86 & 1.22 & 1400 \\
\hline Pulau Biola (PBi) & Fringing & 1 & East & 103.74 & 1.17 & 1700 \\
\hline Pulau Bukom Kechil (PBK) & Fringing & 1 & South & 103.76 & 1.22 & 800 \\
\hline Pulau Busing (PBu) & Fringing & 1 & Northwest & 103.74 & 1.23 & 600 \\
\hline \multirow[t]{2}{*}{ Pulau Hantu (PH) } & Fringing & 2 & South & 103.75 & 1.23 & 200 \\
\hline & Fringing & & South & 103.75 & 1.22 & 500 \\
\hline \multirow[t]{4}{*}{ Pulau Pawai (PP) } & Fringing & 4 & South & 103.72 & 1.18 & 1500 \\
\hline & Fringing & & West & 103.72 & 1.18 & 1100 \\
\hline & Fringing & & North & 103.72 & 1.19 & 800 \\
\hline & Fringing & & East & 103.73 & 1.19 & 1600 \\
\hline Pulau Salu (PSa) & Fringing & 1 & South & 103.71 & 1.22 & 600 \\
\hline Pulau Satumu (PS) & Fringing & 1 & West & 103.74 & 1.16 & 900 \\
\hline \multirow[t]{3}{*}{ Pulau Senang (PSe) } & Fringing & 3 & South & 103.73 & 1.17 & 1300 \\
\hline & Fringing & & Northwest & 103.73 & 1.17 & 600 \\
\hline & Fringing & & Southeast & 103.74 & 1.17 & 2000 \\
\hline \multirow[t]{4}{*}{ Pulau Sudong (PSu) } & Fringing & 4 & West & 103.71 & 1.21 & 600 \\
\hline & Fringing & & South & 103.72 & 1.20 & 2400 \\
\hline & Fringing & & South & 103.72 & 1.20 & 800 \\
\hline & Fringing & & North & 103.72 & 1.21 & 3900 \\
\hline Pemalang (Pem) & Fringing & 1 & Northwest & 103.74 & 1.16 & 400 \\
\hline \multirow[t]{3}{*}{ The Sisters (SI) } & Fringing & 3 & Big Sisters', SE & 103.84 & 1.21 & 100 \\
\hline & Fringing & & Big Sisters', N & 103.83 & 1.22 & 500 \\
\hline & Fringing & & Small Sisters', W & 103.83 & 1.22 & 400 \\
\hline Terembu Bemban (TB) & Patch & 1 & North & 103.74 & 1.21 & 500 \\
\hline Terembu Berkas Besar (TBB) & Patch & 1 & East & 103.74 & 1.20 & 1000 \\
\hline Terembu Pempang Darat (TPD) & Patch & 1 & South & 103.74 & 1.22 & 500 \\
\hline Terembu Pempang Tengah (TPT) & Patch & 1 & West & 103.73 & 1.23 & 400 \\
\hline Terembu Raya (TR) & Patch & 1 & North & 103.75 & 1.22 & 400 \\
\hline
\end{tabular}

multiplied by depth to obtain a better estimate of their numbers at each unit area of reef. Based on previous fecundity and fertilization rate studies (e.g. Van Veghel \& Kahmann 1994, Hughes et al. 2000, Bastidas et al. 2005), the source reefs should produce at least $1.5 \times 10^{6}$ times more viable planulae than the number of particles released in the model. The particle concentrations were therefore also multiplied by a factor of $1.5 \times 10^{6}$.

\section{RESULTS}

Results from Set I simulations indicate that the coral larvae released from the Southern Islands in April 2007 have good potential to recruit locally, providing there is sufficient amount of spawn production by local reefs. The number of particles at each sink site decreased from the day of spawning (Day 0) to a minimum at Day 7 , but increased again until the end of the simulation period (Fig. 4). These results were visualized using video simulations of the model runs (authors' unpubl. data). The larval plume remained in the water surrounding the Southern Islands until the fourth or fifth day, then moved northwest within the Singapore Strait towards the Malacca Strait, and back to the area of the Southern Islands on the ninth or tenth day. The number of particles reaching Raffles Lighthouse, Kusu Island and Pulau Hantu achieved their maximum peak before the larval plume moved northwest towards the Malacca Strait, whereas the maximum peak at the Sisters' Islands and St John's Island occurred only after the larval plume changed direction back into the Singapore Strait towards the Southern Islands (Table 2). Minor fluctuations in the peaks of particles at each of the sink sites are reflective of the semi-diurnal tidal period in Singapore, which is particularly prominent at Raffles Lighthouse (Fig. 4).

Raffles Lighthouse, the reef farthest away from mainland Singapore, and also at the southern tip of the southwestern cluster, was predicted by the model to receive the highest level of larval input among the 5 sink sites and, hence, has the greatest potential for 
Table 2. Predicted maximum $\left(\mathrm{N}_{\mathrm{Max}}\right)$, minimum $\left(\mathrm{N}_{\mathrm{Min}}\right)$ and average $\left(\mathrm{N}_{\mathrm{Avg}}\right)$ numbers of coral larvae found (no. larvae $\mathrm{m}^{-2}$ $\mathrm{d}^{-1}$ ) at each of the sink sites over the $10 \mathrm{~d}$ period of interest under Set I and Set II simulations. $\mathrm{N}_{\mathrm{Max}}$ does not include the first $36 \mathrm{~h}$ after spawning. $\mathrm{T}_{\mathrm{Max}}$ and $\mathrm{T}_{\mathrm{Min}}$ are the respective number of hours post-spawning. Predicted numbers of larvae have been rounded to the nearest whole number. As the total number of particles released from all 18 sources in Set II simulations was almost 2-fold greater than in Set I, the maximum and average numbers of particles found at the sink sites in Set II were also higher, so comparisons were made between the relative ranks of the reefs instead of the absolute numbers of particles recorded

\begin{tabular}{|lccccccc|}
\hline \multicolumn{8}{|c|}{ Number of larvae and hours after spawning } \\
& $\mathrm{N}_{\text {Max }} \mathrm{T}_{\text {Max }}$ & $\mathrm{N}_{\text {Min }} \mathrm{T}_{\text {Min }}$ & $\mathrm{N}_{\text {Avg }}$ & $\mathrm{SE}$ \\
\hline Site & & & & & & \\
& Set I simulations & & & & & & \\
Raffles Lighthouse & 170 & 37 & $<1$ & 175 & 17 & 0.88 \\
Kusu Island & 74 & 47.5 & $<1$ & 135 & 5 & 0.32 \\
Pulau Hantu & 48 & 38 & $<1$ & 189.5 & 5 & 0.23 \\
Sisters' Islands & 36 & 222.5 & $<1$ & 183 & 3 & 0.21 \\
St John's Island & 4 & 249 & $<1$ & 78.5 & 1 & 0.03 \\
& & & & & & \\
Set II simulations & & & & & & \\
Raffles Lighthouse & 207 & 37 & $<1$ & 194.5 & 29 & 1.45 \\
Pulau Hantu & 84 & 38 & $<1$ & 188.5 & 9 & 0.42 \\
Sisters' Islands & 133 & 247 & $<1$ & 174.5 & 10 & 0.55 \\
\hline
\end{tabular}

recruitment (Fig. 4); it received an average of 16.8 particles $\mathrm{m}^{-2} \mathrm{~d}^{-1}$ over the $10 \mathrm{~d}$ period of interest (beginning from the 36th hour after spawning) with a peak of 170 particles $\mathrm{m}^{-2}$. This was approximately 17- and 45-fold higher than the respective numbers for St John's Island, which had the lowest recruitment potential (Table 2, compare Fig. 5e with Fig. 5a-d).

We identified 10 of the 18 source reefs that contributed most of the larvae arriving at the 5 sink sites. Pulau Sudong stood out as the strongest potential source reef, followed by Pulau Pawai and Pulau Senang (all 3 of these reefs are within a military Live Firing Area). The Sisters' Islands, Kusu Island, and Pulau Biola were consistently predicted to be among the 6 (together with Pulau Sudong, Pulau Pawai and Pulau Senang) most robust source reefs (Fig. 5). These 6 source reefs also had the highest live coral cover, and therefore the highest numbers of particles released during the Set I simulations (which was proportionate to live coral cover). However, the amount of larval transport did not always correspond to the number of larvae released; even though the same numbers of particles were released from both the Sisters' Islands and Terembu Berkas Besar, the latter reef was not as effective in seeding the 5 sink sites (Fig. 5).

Inter-connectivity among 4 of the sink sites, Pulau Hantu, the Sisters' Islands, Kusu Island and Raffles Lighthouse, was demonstrated in both Set I and Set II models, with greater inclination for east to west flows in most cases, except between the Sisters' Islands and Kusu Island in which larval flow was $3.8 \times$ stronger in the opposite direction. A stronger $(4.8 \times)$ north to south flow was indicated from Pulau Hantu to Raffles Lighthouse. Differences in the strengths of larval traffic between each pair varied. Strong differences in larval flow were identified between Kusu Island and Raffles Lighthouse $(7.2 \times)$, and between the Sisters' Islands and Raffles Lighthouse $(8.9 \times)$, with moderate differences identified between the Sisters' Islands and Kusu Island (3.8×), Pulau Hantu and Raffles Lighthouse $(4.8 \times)$, and Pulau Hantu and Kusu Island $(4.9 \times)$. The asymmetrical exchange between Pulau Hantu and the Sisters' Islands $(1.6 \times)$ was less pronounced (Fig. 5f).

To help determine source sites that could potentially also function as coral nursery grounds, equal numbers of particles were released from each of the source reefs (Set II simulations). Only 3 sink sites were considered in these simulations: Raffles Lighthouse, Pulau Hantu and the Sisters' Islands, to represent the main zones within the Southern Islands (southwestern, central, and eastern clusters, respectively) (Fig. 2). A very different set of 10 'best' source reefs was found in these simulations (Fig. 6) compared with those in Set I (Fig. 5a,c,d). For the Sisters' Islands, contributions from the Sisters' Islands and Kusu Island were greatly increased (compare Figs. $5 \mathrm{~d} \& 6 \mathrm{c})$. For Pulau Hantu, the spatial range of 10 best source reefs was mostly reduced to the reefs immediately surrounding it (compare Figs. 5c \& 6b), apart from the Sisters' Islands and Kusu Island. Overall, for Set II, the Sisters' Islands and Kusu Island were found to be the 2 most influential source reefs, while the coral reefs fringing Pulau Busing and the patch reefs of Beting Bemban Besar were also found to be important larval contributors to the 3 sink sites. Pulau Pawai and Pulau Senang were still among the top 10 source reefs for Raffles Lighthouse, but their contribution relative to that from the Sisters' Islands and Kusu Island were reduced (compare Figs. 5a \& 6a). Pulau Sudong did not appear in the list of top 10 sources for any of the 3 sink sites. Differences in the strengths of larval traffic between each pair of sites were similar to that in Set I simulations (compare Figs. $5 f \& 6 d$ ).

\section{DISCUSSION}

To make informed decisions on how to effectively conserve the remainder of Singapore's coral reefs, it 
a)

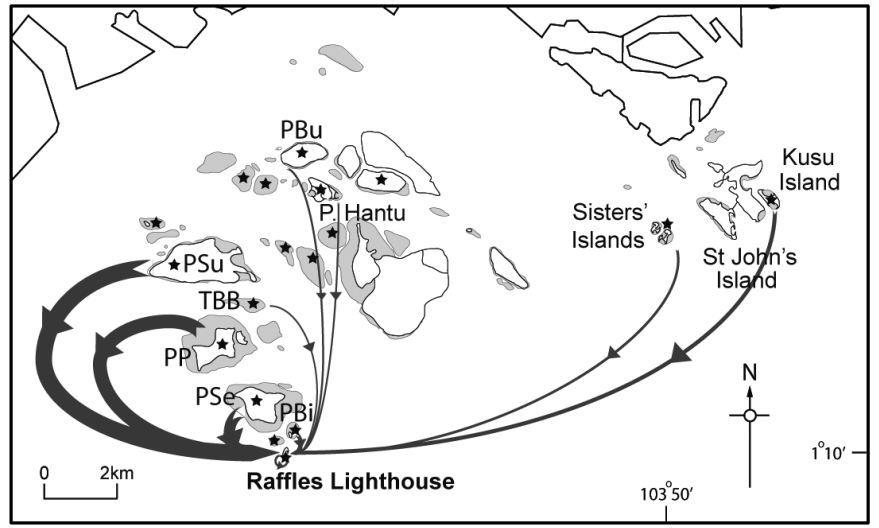

c)

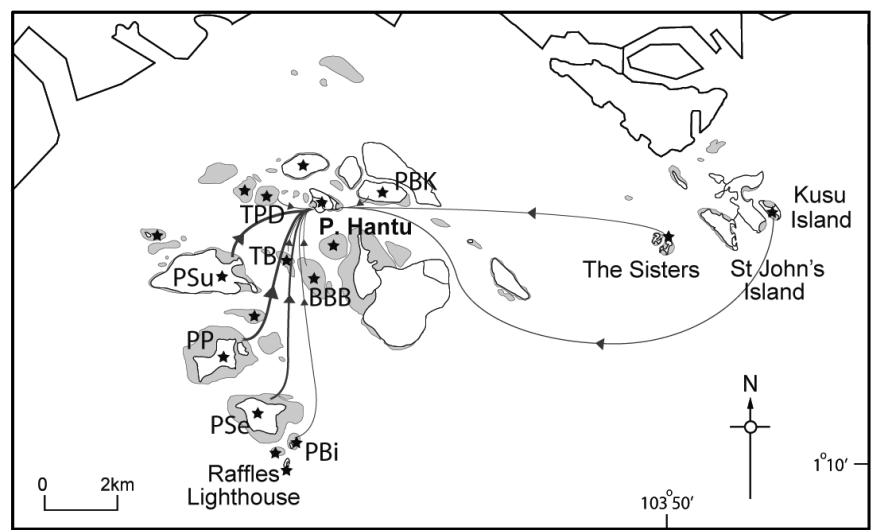

e)

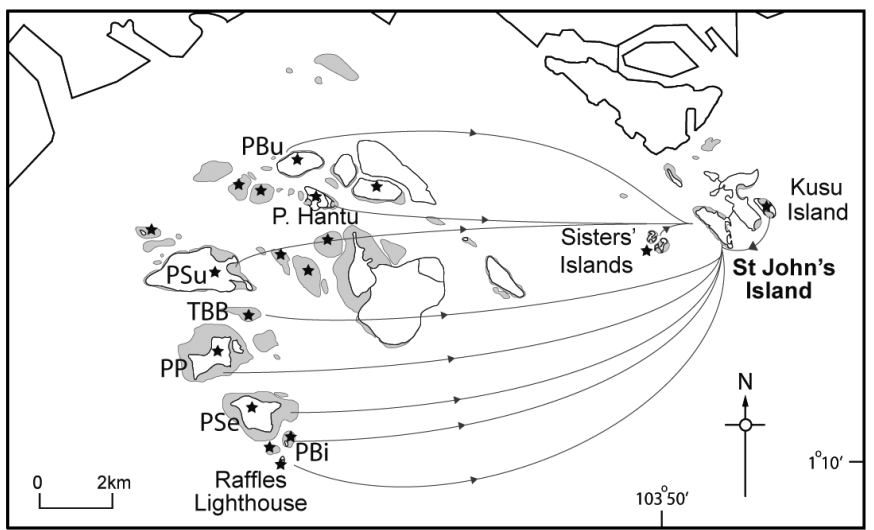

b)

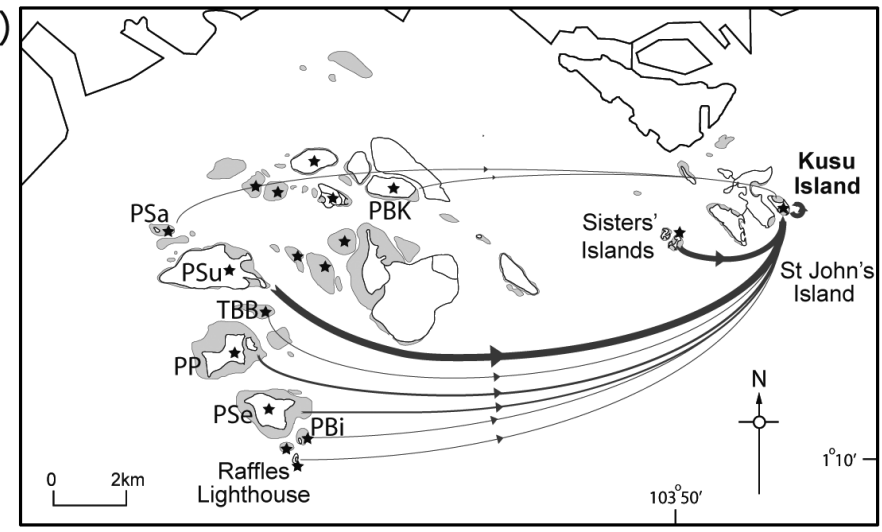

d)

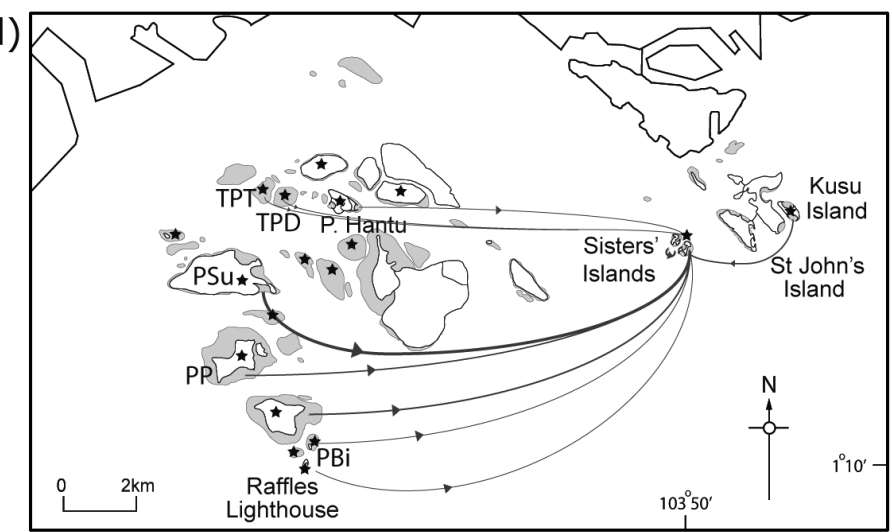

f)

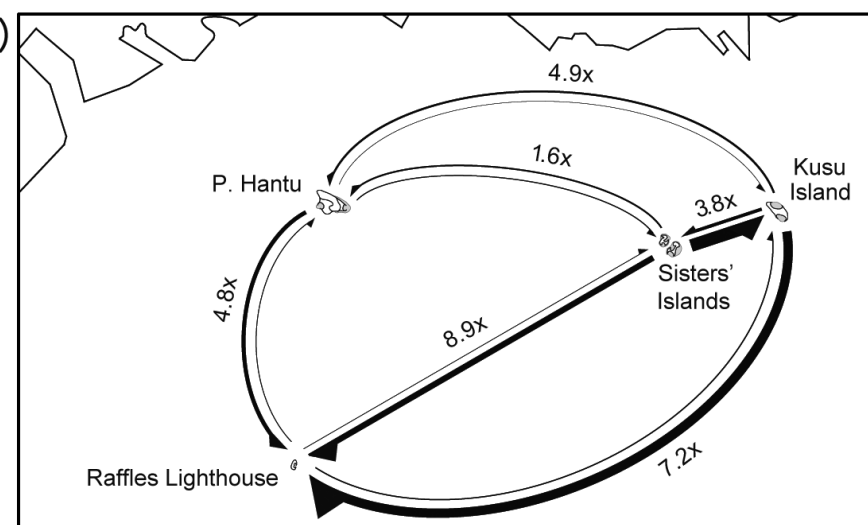

Fig. 5. The 10 (out of a total of 18) source reefs that potentially contribute the majority of larval input at the 5 sink sites: (a) Raffles Lighthouse, (b) Kusu Island, (c) Pulau Hantu (d) the Sisters' Islands and (e) St John's Island, in April 2007. Numbers of particles released in the simulations were proportionate to the live coral cover at each reef (Set I). Thickness of the arrows is proportionate to the predicted number of larvae reaching each sink site over the $10 \mathrm{~d}$ period of interest. Reefs where particles were released from are marked with a $\star$. (f) The network of larval traffic among 4 of the 5 sink sites of interest. Arrows represent general direction only, not the actual path of larvae. See Fig. 2 for definition of reef abbreviations

is necessary to determine coral larval dispersal dynamics among the Southern Islands. The findings of the present study indicate the presence of larvae at the sink sites during the $10 \mathrm{~d}$ period when coral larvae are most competent to settle (e.g. Connolly \& Baird 2010, Tay et al. 2011), suggesting the potential for local recruitment. However, departure of the larval plume from the Southern Islands during the peak larval settlement competency period from the fourth or fifth day to the ninth or tenth day post-spawning means that a significant proportion of the larvae may leave Singapore's waters. Despite the absence of the main larval plume during this critical competency period, some recruitment of coral larvae, at a rate of 1 to $15 \mathrm{~m}^{-2} \mathrm{yr}^{-1}$, has been documented in the Southern Islands (Dikou \& van Woesik 2006, Loh et al. 
a)
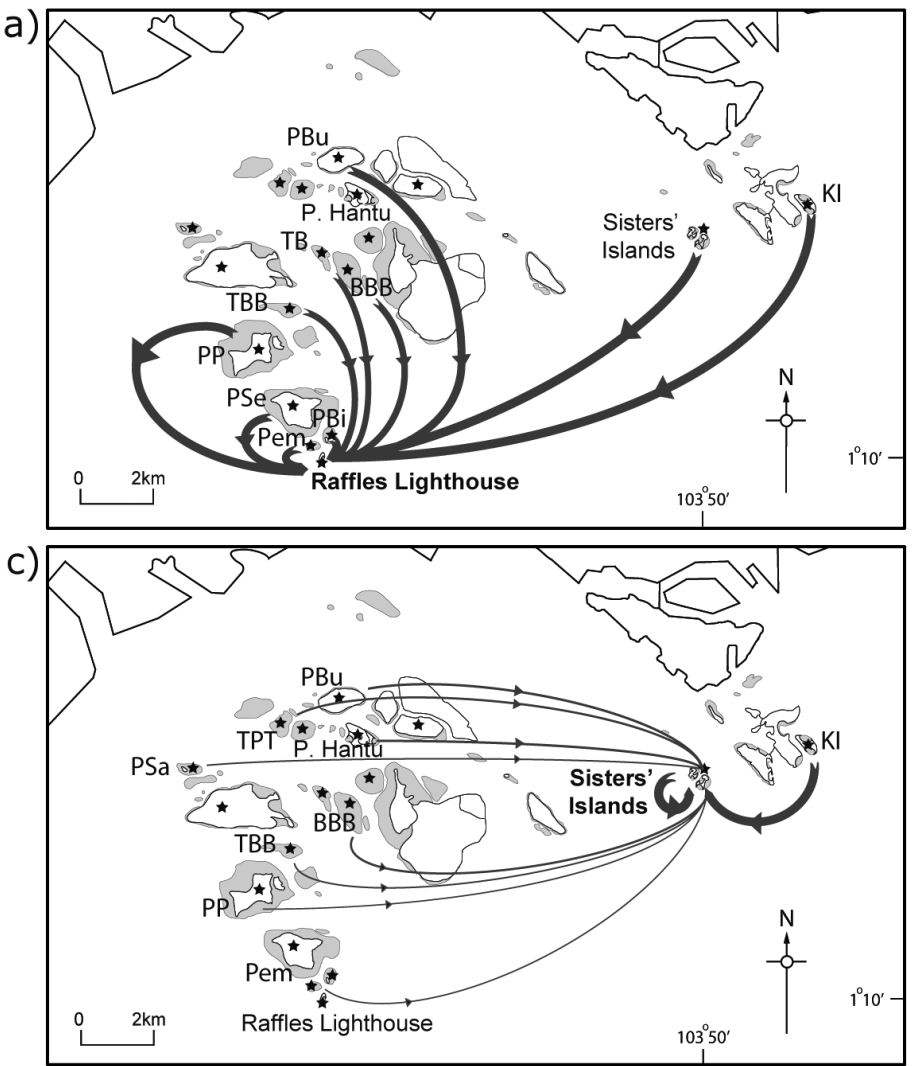

b)

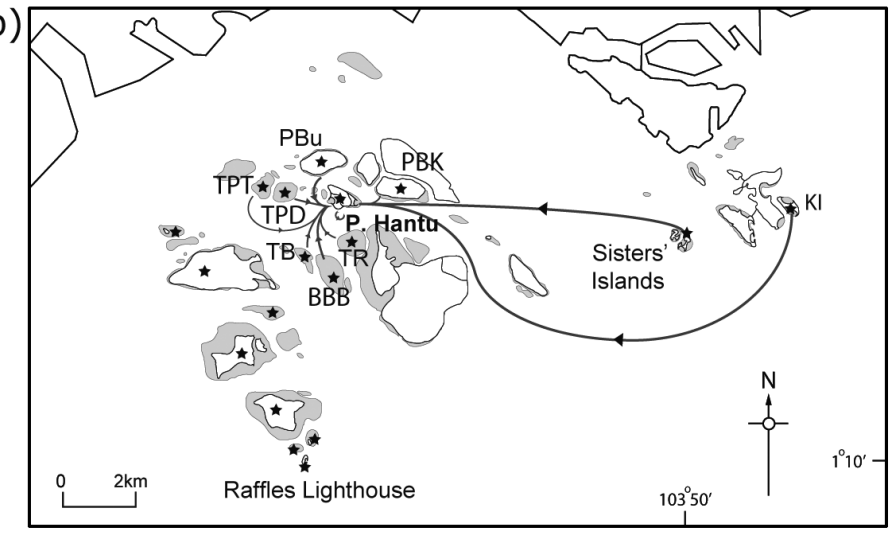

d)

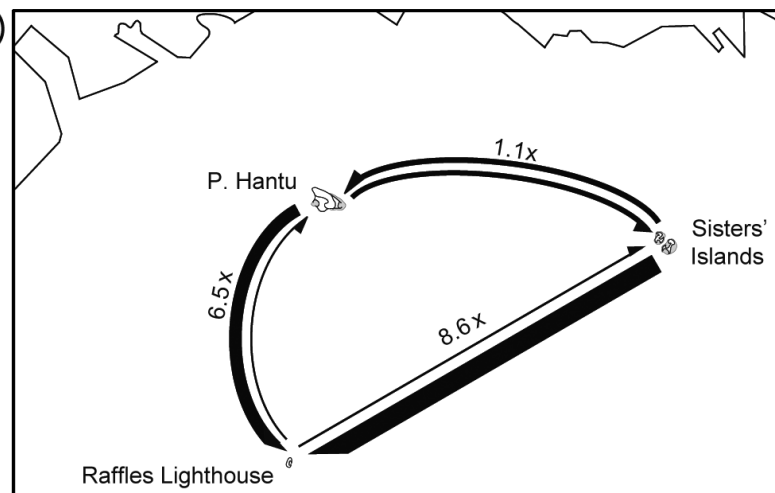

Fig. 6. The 10 (out of a total of 18) source reefs that potentially contribute the majority of larval input at 3 sink sites: (a) Raffles Lighthouse, (b) Pulau Hantu and (c) the Sisters' Islands, in April 2007. Equal numbers of particles were released from each source reef in the simulations (Set II). For symbols and lettering see legends of Figs. 2 \& 5

2006), which is comparable to that of other impacted reefs, such as those at Koh Tao, Thailand (Yeemin et al. 2006), or along the southeast reefs of Florida (Rubin et al. 2008). In Singapore these poor recruitment levels could be due to the sedimented condition of the local reefs (Hodgson 1990, Dikou \& van Woesik 2006), the departure of the larval plume during the main settlement window or a combination of these factors. Some larvae may remain competent to settle beyond the peak period, but if these manage to survive and grow into genetically fit adults they will probably have little ecological effect (they may, however, be important on evolutionary timescales).

Both sets of model simulations indicate that Raffles Lighthouse is probably the best sink reef. This finding is supported by previous studies conducted by Loh et al. (2006) and Dikou \& van Woesik (2006), in which Raffles Lighthouse was found to have higher levels of recruitment compared with St John's Island, Lazarus Island or Cyrene Reef. In particular, Loh et al. (2006) showed Raffles Lighthouse to have a significantly greater recruitment density than that at St John's Island, which is consistent with the model's prediction that St John's is a very poor sink site (Fig. 4). Being located on the southwestern edge of the Southern Islands cluster, i.e. downstream of the net east to west current during the coral spawning season, Raffles Lighthouse is possibly open to a greater window of larval input. Conversely, because St John's Island is situated at the eastern cluster of the Southern Islands, it is upstream of the main current stream and therefore is likely to receive little larval input. This dispersal pattern may also contribute to the high coral cover and scleractinian species richness of Raffles Lighthouse (Huang et al. 2009), although Raffles Lighthouse also has better water quality owing to it being the island farthest away from mainland Singapore (Todd et al. 2004a), as well as more stable substrate, both of which are beneficial to larval recruitment (Lane 1991, Dikou \& van Woesik 2006).

Identifying sink sites is useful, but it is equally important to determine the strongest source reefs. Without an input source, reef populations will become reproductively isolated, functionally compromised and more susceptible to degradation. Pulau 
Sudong, Pulau Pawai and Pulau Senang, which all lie within the Live Firing Area, were predicted as the most robust sources of larvae seeding the rest of the Southern Islands. This area is for exclusive use by the Singapore military, so its reefs face little threat from anthropogenic influence such as exploitation or development (Chou 2008). The coral reefs at these 3 sites are therefore in good condition and have high live coral cover. Since fecundity is positively correlated with recruitment levels (Hughes et al. 2000), it is not surprising that the effectiveness of a source reef is, at least partly, a result of the number of particles emanating from it (Ayata et al. 2009). When equal numbers of particles were released from Pulau Sudong, Pulau Pawai and Pulau Senang, they were replaced by the Sisters' Islands and Kusu Island as the most robust source reefs. The Sisters' Islands and Kusu Island, being in the eastern cluster of reefs, naturally became the most effective sources because they are upstream from the prevalent current in the Singapore Strait. Hence, even though these islands may not be major source reefs with their present moderate cover of live coral, they may become important dispersal sources if the reefs could be improved.

Closer inspection of the larval flow patterns reveals interesting small scale patterns of inter-connectivity among the Sisters' Islands, Raffles Lighthouse, Kusu Island and Pulau Hantu (Fig. 5f). Given their proximities to each other (2 to $20 \mathrm{~km}$ apart), a high level of bi-directional transfer of larvae might be expected, but the traffic between most of these reefs was predicted by the model to be dominated by flows in one direction. Dikou \& van Woesik (2006) proposed that the reefs of the Southern Islands are not interconnected because peak recruitment of Pocillopora larvae at Raffles Lighthouse and Cyrene Reef did not coincide. They also noted that Acropora occurs at substantial densities only at Raffles Lighthouse (Dikou \& van Woesik 2006). Todd et al. (2001) observed that the small-scale morphology of the massive coral Favia speciosa varied significantly among Cyrene Reef, Pulau Hantu and Raffles Lighthouse and suggested that this is a result of limited gene flow. The Southern Islands, however, could still be genetically connected through generations of lowlevel coral larval transfer, possibly 'transiting' via other nearby reefs, especially Raffles Lighthouse, which receives genetic input from numerous sites (Fig. 5a,b). Incongruent peaks of Pocillopora recruitment do not necessarily reflect a lack of connectivity as larval flows between reefs may vary in magnitude and timing (Fig. 5). Acropora is possibly only found in abundance at Raffles Lighthouse owing to its inabil- ity to tolerate the environmental conditions, especially sedimentation (Sanders \& Baron-Szabo 2005), at reefs closer to the mainland. Finally, subsequent studies by Todd et al. $(2004 \mathrm{a}, \mathrm{b})$ demonstrated that $F$. speciosa is phenotypically plastic and, therefore, this species could simply have adjusted its morphology in accordance to its immediate surroundings.

Any evaluation of the results of this study should note the assumptions made in the simulations. We were mainly interested in the patterns of larval dispersal within the Southern Islands in order to identify the strongest source and sink sites, and not the actual numbers of larvae per se. Many factors can affect the numbers dispersed, including the amount of gametes released, fertilization success and mortality rates. For instance, Connolly \& Baird (2010) demonstrated that initial high mortality rates of larvae, especially when coupled with variations in competency periods, are likely to affect dispersal potentials in several coral species. Constant mortality rates tend to overestimate larval retention at natal reefs but underestimate long-distance dispersal, while fixed competencies among larvae in a cohort are likely to underestimate both near and distant dispersal (Connolly \& Baird 2010). The zero mortality assumed in the model simulations used in the present study may result in an overestimation of connectivity among the Southern Islands, simply because the larvae are given a greater window of opportunity to travel to more sites for settlement. Mortality rates of invertebrate larvae are usually high (Graham et al. 2008, Vermeij \& Sandin 2008), but exactly how high is dependent on numerous factors that include water temperature (Nozawa \& Harrison 2007), sedimentation levels (Gilmour 1999), predation (Baird et al. 2001) and salinity (Vermeij et al. 2006), all of which complicate realized larval settlement and recruitment. Furthermore, larval availability does not necessarily lead to settlement or recruitment (Pineda et al. 2010). Habitat selection occurs in coral larvae (Harrington et al. 2004, Golbuu \& Richmond 2007), and larval settlement in the models was based on the assumption that existing coral reefs provided suitable settlement and cues for metamorphosis (cf. Baums et al. 2006). These processes, therefore, cannot be simply incorporated using a scaling factor as they are often non-linear, prone to stochasticity and vary among sites. Nevertheless, the validations of the hydrodynamics used in the present model are robust and the fundamental patterns of dispersal identified should be retained regardless of the issues listed above.

Our model simulations were run in a 2D hydrodynamic model, which did not account for the effects 
of changes in vertical larval distribution on dispersal, even though vertical swimming behaviour can affect dispersal distances in other marine taxa (e.g. Gilbert et al. 2010, Tilburg et al. 2010) and has been suggested in coral larvae (e.g. Stake \& Sammarco 2003, Szmant \& Meadows 2006). However, unless the larvae are strictly bottom dwellers, or swim rapidly in response to changes in tide following a 'squarewave' instead of 'sine-wave' (slow swimming) migration pattern as reported in Sundelöf \& Jonsson (2012), the effect of vertical swimming on transport is not likely to be significant. The dispersal distances described in this paper should be reliable for coral larvae that stay in the water column for longer periods of time, for example Platygyra sinensis, but may be an over-estimation for more benthic coral species such as Pectinia lactuca, which tend to sink soon after fertilization (Tay et al. 2011).

Several early recommendations for reef management can be made based on the results of the present study. (1) Reefs which are robust source or sink sites can be prioritized for protection and conservation. Pulau Sudong, Pulau Pawai and Pulau Senang are of particular interest as these reefs were demonstrated by the model to serve as major sources of larval production, primarily owing to hosting some of the highest live coral cover in Singapore. Fortunately, they are all protected de facto owing to their militarized status. Similarly, the area around Raffles Lighthouse, identified as one of the strongest sink sites, cannot be entered by the general public. The Sisters' Islands and Kusu Island, which have substantial live coral cover and were also found to be strong source reefs for local seeding, presently have no form of conservation classification. This status should be reviewed. (2) Coral reef managers could explore the possibility of enhancing potential source sites with a view to improve gamete release. Again, the Sisters' Islands and Kusu Island stand out as suitable candidates as larval transport is facilitated by the net east to west current. Coral transplantation efforts could target these areas (Horoszowski-Fridman et al. 2011), while midwater floating nurseries deployed here may act as larval export hubs (Amar \& Rinkevich 2007). (3) Mitigation measures for reclamation works, particularly in downstream, western Singapore (such as the project to extend the Tuas Peninsula), should incorporate retaining rock walls around the reclaimed land similar to the ones at Pulau Semakau in Singapore. Rock walls that extend beyond the intertidal area have proven to be good substrates for coral larval recruitment, and since coral larvae tend to be transported to the west, they are likely to promote coral reef development as has happened at Pulau Semakau (Goh 2007).

This is only a preliminary study of the larval dispersal patterns within Singapore's Southern islands, using passive particles with no biological properties. More complex models could be tested, possibly incorporating a finer mesh size, 3D hydrodynamics and the biological properties of coral larvae and potentially other taxa (Kinlan et al. 2005). Currently, it is an inadequate knowledge of coral larval behaviour, not the numerical models, that is hindering progress understanding larval dispersal (as reviewed in Pineda et al. 2007), and model predictions rely heavily on assumptions (James et al. 2002). Moreover, what little available information exists is often incompatible with hydrodynamic models, including the one used in the present study. More effective communication between modellers and biologists is required to bridge the differences between the data required for hydrodynamic models and those collected on larval biology. Population genetic studies, which are currently underway in Singapore, can also be used to validate model results and may reveal new insights (Galindo et al. 2010, Kininmonth et al. 2010). For Singapore, widening the models' scope to encompass Indonesian reefs is important. The coral reefs along the northern coast of Pulau Batam and Pulau Bintan, Indonesia, which line the southern border of the Singapore Strait, have great potential to seed the reefs of the Southern Islands. They are upstream from the east to west current that exists during the main multispecies coral spawning season and are generally less degraded than reefs within Singapore. If all the Singapore Strait reefs were found to be connected, it could have important implications for coral reef managers, as conservation efforts would necessitate collaborative transboundary management between these 2 neighbouring countries.

Acknowledgements. We are grateful to DHI Water \& Environment, Singapore, for allowing us to use their software: MIKE 21. Special thanks go to T. Foster, J. Dorge, T. Uhrenholdt, P. S. Rasch, L. H. Tan and C. Pui for their invaluable advice and technical support. We also thank 3 anonymous reviewers, P.W. Sammarco, and P. Erftemeijer for their comments on drafts of this manuscript. This research was supported by a grant from the National Parks Board of Singapore (grant no. R-154-000-411-490).

\section{LITERATURE CITED}

Amar KO, Rinkevich B (2007) A floating mid-water coral nursery as larval dispersion hub: testing an idea. Mar Biol 151:713-718 
Atchison A, Sammarco PW, Brazeau D (2008) Genetic connectivity in corals on the Flower Garden Banks and surrounding oil/gas platforms, Gulf of Mexico. J Exp Mar Biol Ecol 365:1-12

Ayata SD, Ellien C, Dumas F, Dubois S, Thiébaut E (2009) Modelling larval dispersal and settlement of the reefbuilding polychaete Sabellaria alveolata: role of hydroclimatic processes on the sustainability of biogenic reefs. Cont Shelf Res 29:1605-1623

> Babcock RC, Heyward AJ (1986) Larval development of certain gamete-spawning scleractinian corals. Coral Reefs 5:111-116

> Babu M, Vethamony P, Desa E (2005) Modelling tide-driven currents and residual eddies in the Gulf of Kachchh and their seasonal variability: a marine environmental planning perspective. Ecol Model 184:299-312

Baird AH, Pratchett MS, Gibson DJ, Koizumi N, Marquis CP (2001) Variable palatability of coral eggs to a planktivorous fish. Mar Freshw Res 52:865-868

> Bastidas C, Croquer A, Zubillaga AL, Ramos R, Kortnik V, Weinberger C, Marquez LM (2005) Coral mass- and split-spawning at a coastal and an offshore Venezuelan reefs, southern Caribbean. Hydrobiologia 541:101-106

Baums IB, Paris CB, Chérubin LM (2006) A bio-oceanographic filter to larval dispersal in a reef-building coral. Limnol Oceanogr 51:1969-1981

Black KP (1993) The relative importance of local retention and inter-reef dispersal of neutrally buoyant material on coral reefs. Coral Reefs 12:43-53

Brazeau DA, Sammarco PW, Atchison AD (2011) Microscale genetic heterogeneity and structure in coral recruitment: fine-scale patchiness. Aquat Biol 12:55-67

> Chen M, Mural K, Khoo BC, Lou J, Kumar K (2005) Circulation modelling in the Strait of Singapore. J Coast Res 21:960-972

> Chia FS, Buckland-Nicks J, Young CM (1984) Locomotion of marine invertebrate larvae: a review. Can J Zool 62:1205-1222

Chou LM (1996) Response of Singapore reefs to land reclamation. Galaxea 13:85-92

Chou LM (2006) Marine habitats in one of the world's busiest harbours. In: Wolanski E (ed) The environment in Asia Pacific Harbours. Springer, New York, NY, p 377-391

Chou LM (2008) Nature and sustainability of the marine environment. In: Wong TC, Yuen B, Goldblum C (eds) Spatial planning for a sustainable Singapore. Springer Science+Business Media, Philadelphia, PA, p 169-182

Chou LM, Tun KPP (2005) Singapore. In: Status of coral reefs in East Asian Seas region: 2004. Government of Japan, Ministry of the Environment, Tokyo, p 53-69

> Chou LM, Tun KPP (2007) Conserving reefs beside a marine landfill in Singapore. Coral Reefs 26:719

> Connolly SR, Baird AH (2010) Estimating dispersal potential for marine larvae: dynamic models applied to scleractinian corals. Ecology 91:3572-3583

> Cowen RK, Sponaugle S (2009) Larval dispersal and marine population connectivity. Annu Rev Mar Sci 1:443-466

DHI (2009) MIKE 21/3 Flow Model FM hydrodynamic and transport module scientific documentation. DHI Group, Hørsholm

DHI (2011) MIKE 21/3 Flow Model FM particle tracking module scientific documentation. DHI Group, Hørsholm

> Dikou A, van Woesik R (2006) Survival under chronic stress from sediment load: spatial patterns of hard coral communities in the southern islands of Singapore. Mar Pollut
Bull 52:1340-1354

Doorn-Groen SM (2007) Environmental monitoring and management of reclamation works close to sensitive habitats. Terra Aqua 108:3-18

> Fiechter J, Haus BK, Melo N, Mooers CNK (2008) Physical processes impacting passive particle dispersal in the Upper Florida Keys. Cont Shelf Res 28:1261-1272

Fitzhardinge R (1985) Spatial and temporal variability in coral recruitment in Kaneohe Bay. Proc 5th Int Coral Reef Congr, Tahiti 4:373-378

Galindo HM, Pfeiffer-Herbert AS, McManus MA, Chao Y, Chai F, Palumbi SR (2010) Seascape genetics along a steep cline: using genetic patterns to test predictions of marine larval dispersal. Mol Ecol 19:3692-3707

Gilbert CS, Gentleman WC, Johnson CL, DiBacco C, Pringle JM, Chen C (2010) Modelling dispersal of sea scallop (Placopecten magellanicus) larvae on Georges Bank: the influence of depth-distribution, planktonic duration and spawning seasonality. Prog Oceanogr 87:37-48

Gilmour J (1999) Experimental investigation into the effects of suspended sediment on fertilization, larval survival and settlement in a scleractinian coral. Mar Biol 135: 451-462

Gleason DF, Danilowicz BS, Nolan CJ (2009) Reef waters stimulate substratum exploration in planulae of brooding Caribbean corals. Coral Reefs 28:549-554

Goh E (2007) Singapore's coral reefs: the next step in its rehabilitation and long term management. MSc thesis, National University of Singapore

Goh N (2009) Management for long-term sustainability of marine habitats in Singapore: a science-based approach. Raffles Bull Zool Suppl 22:279-282

Goh E, Chou LM, Tun K, Foster T (2007) The accidental reef - creative reef restoration in land scarce Singapore. Abstracts of the 11th Int Coral Reef Symp, Ft Lauderdale, p 534 (Abstract)

Golbuu Y, Richmond RH (2007) Substratum preferences in planulae larvae of two species of scleractinian corals, Goniastrea retiformis and Stylaraea punctata. Mar Biol 152:639-644

Graham EM, Baird AH, Connolly SR (2008) Survival dynamics of scleractinian coral larvae and implications for dispersal. Coral Reefs 27:529-539

Guest JR, Chou LM, Baird AH, Goh BPL (2002) Multispecific, synchronous coral spawning in Singapore. Coral Reefs 21:422-423

> Guest JR, Baird AH, Goh BPL, Chou LM (2005) Reproductive seasonality in an equatorial assemblage of scleractinian corals. Coral Reefs 24:112-116

> Harrington LM, Fabricius K, Dea'th G, Negri A (2004) Habitat selection of settlement substrata determines postsettlement survival in corals. Ecology 85:3428-3437

> Hodgson G (1990) Sediment and the settlement of larvae of the reef coral Pocillopora damicornis. Coral Reefs 9: $41-43$

> Horoszowski-Fridman YB, Izhaki I, Rinkevich B (2011) Engineering of coral reef larval supply through transplantation of nursery-farmed gravid colonies. J Exp Mar Biol Ecol 399:162-166

Huang D, Chou LM, Todd PA, Ang KH, Boon PY, Cheng L (2006a) Algal and invertebrate diversity of the intertidal zone at Labrador Nature Reserve, Singapore. Malay Nat J 59:93-102

Huang D, Todd PA, Chou LM, Ang KH and others (2006b) Effects of shore height and visitor pressure on the diver- 
sity and distribution of four intertidal taxa at Labrador Beach, Singapore. Raffles Bull Zool 54:477-484

Huang D, Tun KPP, Chou LM, Todd PA (2009) An inventory of zooxanthellate scleractinian corals in Singapore, including 33 new records. Raffles Bull Zool Suppl 22:69-80

Hughes TP (1994) Catastrophes, phase shifts, and largescale degradation of a Caribbean coral reef. Science 265: 1547-1551

Hughes TP, Baird AH, Dinsdale EA, Moltschaniwskyj NA, Pratchett MS, Tanner JE, Willis BL (2000) Supplyside ecology works both ways: the link between benthic adults, fecundity, and larval recruits. Ecology 81 : 2241-2249

Hughes TP, Baird AH, Bellwood DR, Card M and others (2003) Climate change, human impacts, and the resilience of coral reefs. Science 301:929-933

James MK, Armsworth PR, Mason LB, Bode L (2002) The structure of reef fish metapopulations: modelling larval dispersal and retention patterns. Proc Royal Soc London B 269:2079-2086

Jones OP, Petersen OS, Kofoed-Hansen H (2007) Modelling of complex coastal environments: some considerations for best practice. Coast Eng 54:717-733

Kininmonth S, van Oppen MJH, Possingham HP (2010) Determining the community structure of the coral Seriatopora hystrix from hydrodynamic and genetic networks. Ecol Model 221:2870-2880

Kinlan BP, Gaines SD, Lester SE (2005) Propagule dispersal and the scales of marine community process. Divers Distrib 11:139-148

Kool JT, Paris CB, Barber PH, Cowen RK (2011) Connectivity and the development of population genetic structure in Indo-West Pacific coral reef communities. Global Ecol Biogeogr 20:695-706

Lane DJW (1991) Growth of scleractinian corals on sediment-stressed reefs at Singapore. In: Alcala AC (ed) Proc Reg Symp Living Resources in Coastal Areas, Manila. Marine Science Institute, University of the Philippines, Manila, p 97-106

Lawrence J, Kofoed-Hansen H, Chevalier C (2009) Highresolution metocean modelling at EMEC's (UK) marine energy test sites. In: Proc 8th Eur Wave and Tidal Energy Conf, Uppsala. www.emec.org.uk/pdf/lawrence_johnhigh-resolution_metocean_modelling_at_emec.pdf

Levin LA (2006) Recent progress in understanding larval dispersal: new directions and digressions. Integr Comp Biol 46:282-297

Lipcius RN, Eggleston DB, Schreiber SJ, Seitz RD and others (2008) Importance of metapopulation connectivity to restocking and restoration of marine species. Rev Fish Sci 16:101-110

Loh T, Tanzil JTI, Chou LM (2006) Preliminary study of community development and scleractinian recruitment on fiberglass artificial reef units in the sedimented waters of Singapore. Aquat Conserv 16:61-76

> Lugo-Fernández A, Deslarzes KJP, Price JM, Boland GS, Morin MV (2001) Inferring probable dispersal of Flower Garden Banks coral larvae (Gulf of Mexico) using observed and simulated drifter trajectories. Cont Shelf Res 21:47-67

> Miller KJ, Mundy CN (2003) Rapid settlement in broadcast spawning corals: implications for larval dispersal. Coral Reefs 22:99-106

Mitarai S, Siegel DA, Winters KB (2008) A numerical study of stochastic larval settlement in the Californian Current system. J Mar Syst 69:295-309

> Nozawa Y, Harrison PL (2007) Effects of elevated temperature on larval settlement and post-settlement survival in scleractinian corals, Acropora solitaryensis and Favites chinensis. Mar Biol 152:1181-1185

Oliver JK, King BA, Willis BL, Babcock RC, Wolanksi E (1992) Dispersal of coral larvae from a lagoonal reef - II. Comparisons between model predictions and observed concentrations. Cont Shelf Res 12:873-889

> Palumbi SR (2003) Population genetics, demographic connectivity, and the design of marine reserves. Ecol Appl 13:146-158

Pang WC, Tkalich P (2003) Modelling tidal and monsoon driven currents in the Singapore Strait. SMPJ Singap Marit Port J 2003:151-162

Pedersen OP, Nilssen EM, Jørgensen LL, Slagstad D (2006) Advection of the red king crab larvae on the coast of North Norway-a Lagrangian model study. Fish Res 79:325-326

Pineda J, Hare JA, Sponaugle S (2007) Larval transport and dispersal in the coastal ocean and consequences for population connectivity. Oceanography 20:22-39

Pineda J, Porri F, Starczak V, Blythe J (2010) Causes of decoupling between larval supply and settlement and consequences for understanding recruitment and population connectivity. J Exp Mar Biol Ecol 392:9-21

Roughan M, Macdonald HS, Baird ME, Glasby TM (2011) Modelling coastal connectivity in a Western Boundary Current: seasonal and inter-annual variability. Deep-Sea Res II 58:628-644

Rubin ET, Moulding AL, Lopez JV, Gilliam DS, Kosmynin VN, Dodge RE (2008) Scleractinian coral recruitment to reefs physically damaged by ship groundings. Proc 11th Int Coral Reef Symp, Ft Lauderdale 10:7-10

Sammarco PW (1994) Larval dispersal and recruitment processes in Great Barrier Reef corals: analysis and synthesis. In: Sammarco PW, Heron ML (eds) The bio-physics of marine larval dispersal. American Geophysical Union, Washington, DC, p 35-72

Sammarco PW (1996) Comments on coral reef regeneration, bioerosion, biogeography, and chemical ecology: future directions. J Exp Mar Biol Ecol 200:135-168

Sammarco PW, Andrews JC, Risk MJ (1991) Coral reef geomorphology as a function of seasonal prevailing currents and larval dispersal. Palaeogeogr Palaeoclimatol Palaeoecol 88:1-12

Sanders D, Baron-Szabo RC (2005) Scleractinian assemblages under sediment input: their characteristics and relation to the nutrient input concept. Palaeogeogr Palaeoclimatol Palaeoecol 216:139-181

> Sanderson PG (2001) The application of satellite remote sensing to coastal management in Singapore. Ambio 30:43-48

Savina M, Lacroix G, Ruddick K (2010) Modelling the transport of common sole larvae in the southern North Sea: influence of hydrodynamics and larval vertical movements. J Mar Syst 81:86-98

Scheltema RS, Williams IP (1983) Long-distance dispersal of planktonic larvae and the biogeography and evolution of some Polynesian and Western Pacific mollusks. Bull Mar Sci 33:545-565

Shafir S, Edwards AJ, Rinkevich B, Bongiorni L, Levy G, Shaish L (2010) Constructing and managing nurseries for asexual rearing of corals. In: Edwards AJ (ed) Reef rehabilitation manual. The Coral Reef Targeted Research \& Capacity Building for Management Program, Melbourne, p 49-72 
Stake JL, Sammarco PW (2003) Effects of pressure on swimming behavior in planula larvae of the coral Porites astreoides (Cnidaria, Scleractinia). J Exp Mar Biol Ecol 288:181-201

Sundelöf A, Jonsson PR (2012) Larval dispersal and vertical migration behaviour - a simulation study for short dispersal times. PSZN I: Mar Ecol 33:183-193

Szmant AM, Meadows MG (2006) Developmental changes in coral larval buoyancy and vertical swimming behaviour: implications for dispersal and connectivity. In: Proc 10th Int Coral Reef Symp, Okinawa, p 431-437

Tanzil JTI, Todd PA, Chou LM (2008) Coral recruitment in sediment-stressed reefs: effect of reef zone and substrate inclination. Abstracts of the 11th Int Coral Reef Symp, Ft Lauderdale, p 521 (Abstract)

Tay YC, Guest JR, Chou LM, Todd PA (2011) Vertical distribution and settlement competencies in broadcast spawning coral larvae: implications for dispersal models. J Exp Mar Biol Ecol 409:324-330

Tilburg CE, Seay JE, Bishop TD, Miller HL III, Meile C (2010) Distribution and retention of Petrolisthes armatus in a coastal plain estuary: the role of vertical movement in larval transport. Estuar Coast Shelf Sci 88:260-266

Tkalich P, Pang WC, Sundarambal P (2002) Hydrodynamics and eutrophication modelling for Singapore Straits. In: Proc 7th Workshop on Ocean Models for the APEC Region, Singapore, p 5.1-5.9)

Todd PA, Chou LM (2005) A tale of survival: Labrador Park, Singapore. Coral Reefs 24:391

Editorial responsibility: Hans-Heinrich Janssen, Oldendorf/Luhe, Germany
Todd PA, Sanderson PG, Chou LM (2001) Morphological variation in the polyps of the scleractinian coral Favia speciosa (Dana) around Singapore. Hydrobiologia 444: 227-235

Todd PA, Ladle RJ, Lewin-Koh NJI, Chou LM (2004a) Genotype $\times$ environment interactions in transplanted clones of the massive corals Favia speciosa and Diploastrea heliopora. Mar Ecol Prog Ser 271:167-182

Todd PA, Ladle RJ, Lewin-Koh NJI, Chou LM (2004b) Flesh or bone? Quantifying small-scale coral morphology using with-tissue and without-tissue techniques. Mar Biol 145: 323-328

> Tuck GN, Possingham HP (2000) Marine protected areas for spatially structured exploited stocks. Mar Ecol Prog Ser 192:89-101

Van Veghel MLJ, Kahmann MEH (1994) Reproductive characteristics of the polymorphic Caribbean reef building coral Montastrea annularis. II. Fecundity and colony structure. Mar Ecol Prog Ser 109:221-227

> Vermeij MJA, Sandin SA (2008) Density-dependent settlement and mortality structure the earliest life phases of a coral population. Ecology 89:1994-2004

> Vermeij MJA, Fogarty ND, Miller MW (2006) Pelagic conditions affect larval behavior, survival, and settlement patterns in the Caribbean coral Montastraea faveolata. Mar Ecol Prog Ser 310:119-128

> Yeemin T, Sutthacheep M, Pettongma R (2006) Coral reef restoration projects in Thailand. Ocean Coast Manag 49:562-575

Submitted: May 13, 2011; Accepted: March 22, 2012 Proofs received from author(s): May 24, 2012 